\title{
'None of you will believe it': Control, truth and myth in the life of Billy McMahon
}

PATRICK MULLINS

\section{Introduction}

Widely regarded as one of Australia's worst prime ministers, William-'Billy' McMahon laboured in his retirement to produce an autobiography that would put forward the story of his life and laudable career as he saw it. But McMahon's inability to reconcile that story with the archive of documents he had compiled, and the stories that his colleagues told in their own books, ensured that progress on his autobiography would be incomplete by the time of his death in 1988. This essay traces McMahon's efforts to assert control of his story, via his archive and work with ghost-writers and publishers on his autobiography, and the effect that this had on the biography of McMahon that I published in 2018. ${ }^{1}$ I reflect on the two stories that my biography tells_-of McMahon's life, as I have understood it, and McMahon's attempts to understand and portray his life-and the effect of each on the ontological stability and certainty of the other.

\section{A 'contemptible little squirt'?}

William-or Billy-McMahon (1908-1988) is commonly regarded as one of Australia's worst prime ministers. ${ }^{2}$ Coming to office in 1971, after more than 20 years continuous service as a minister in the Menzies, Holt and Gorton governments, McMahon's time as prime minister was to be short and fraught. Vicious party infighting, a reactive policy agenda and a loss of public confidence in McMahon's capacities to handle affairs all combined to erode the government's standing in the polls. In December 1972, after 21 months in office, McMahon led the LiberalCountry Party Government to defeat at the election that brought the Whitlam-led Labor Party to power. It left him an ignoble figure.

1 Patrick Mullins, Tiberius with a Telephone: The Life and Stories of William McMahon (Brunswick, Vic.: Scribe, 2018).

2 Paul Strangio, 'Evaluating Prime-Ministerial Performance: The Australian Perspective', in Understanding PrimeMinisterial Performance: Comparative Perspectives, ed. Paul Strangio, Paul 't Hart and James Walter (Oxford: Oxford University Press, 2013), 264-90. 
He was already controversial. Beneath the veneer of public civility, McMahon had been much disliked by his colleagues. Robert Menzies called him a 'contemptible little squirt' and 'the most characterless man ever to have been prime minister' ${ }^{3}$ During the Holt Government (1966-67), in a dispute that was policy-based and intensely personal, McMahon had warred with the Country Party leader, deputy prime minister and minister for trade, John McEwen. When Holt drowned in 1967, McEwen humiliated McMahon-first by vetoing his putative candidacy to succeed Holt, and then by helping a relative newcomer, in John Gorton, to become prime minister (1968-71). Antipathy between Gorton and McMahon was also pronounced. After the 1969 election, McMahon unsuccessfully challenged Gorton for the Liberal Party leadership; was moved against his will to the External Affairs (later, Foreign Affairs) portfolio; succeeded Gorton as prime minister in 1971 amid spectacular circumstances; and then sacked Gorton from the defence ministry five months later for leaking from Cabinet.

In the years that followed the government's loss of office, the divisive regard for McMahon from his colleagues became public. The Liberal Party's attempts to distance itself from him involved some airing of the aforementioned internal disputes; in subsequent decades, the publication of autobiographies and diaries by contemporaries confirmed that 'contemptible little squirt' was far from the worst that had been said of McMahon. The advent of more subjective journalism in the 1970s and 1980s similarly revealed harsher assessments of McMahon than might have been made in earlier eras, and seemingly confirmed McMahon's poor reputation.

McMahon remained in parliament for almost a decade after his prime ministership, serving largely on the backbench. He was aware of his reputation and how it might outlive him. He believed, however, that his reputation was wrong and that the record of his time in government had been marred by distortions and inaccuracies. In January 1982, he resigned from parliament promising that he would correct the record with an autobiography.

Over the next six years, McMahon would labour over that autobiography, writing and rewriting in hopes of finishing a book that would correct the record and prompt the reassessment he believed was his due. But nothing of that book would be published by the time of his death, in 1988, and in its absence a broad consensus formed about him—that he was, truly, Australia's worst prime minister.

I began researching McMahon's life with a view to writing his biography in 2014. Having completed a $\mathrm{PhD}$ on the biographies of contemporary political figures in Australia, I was looking for a challenge and believed myself prepared for the issues that I would encounter in producing the book that eventuated. Looking back on the biography now, the most immediately pressing, the most enduring and the most 
influential issue lay in the interstices of control, truth and myth in McMahon's life, story and archive. The aim of this essay is to account for how these factors influenced my work; in particular, how it led me to the alternating structure of the book-the life of William McMahon, and the stories of William McMahon.

\section{'Ownership and control will, of course, remain with me'}

Throughout his political career, William McMahon maintained and grew a voluminous archive of official and unofficial papers that included cabinet submissions and minutes, defence reports, diplomatic cables, economic and industry briefings, speeches, correspondence, extracts from Hansard, books, pamphlets, newspaper and magazine clippings, and a series of aides-mémoire of his own authorship of events and conversations that he thought significant. Of some use to him during his career, he was well aware of the historical value of this material afterwards, and therefore intent on ensuring that he retained control and ownership of it.

He most notably exercised this after the loss of government in 1972. Within days of the 2 December election, erstwhile government staffers working at McMahon's instruction assembled, packed and temporarily stored in the Department of the Prime Minister and Cabinet (PM\&C) 'certain papers' from the McMahon office. These were then transferred, again at McMahon's instruction and without input from PM\&C officials, to the National Library of Australia alongside various tapes and recordings from the press office. McMahon's press secretary, Reg MacDonald, meanwhile had transferred to his home a batch of papers from the press office. In addition to papers relating to the McMahon Government, this 'batch' included records of the Menzies, Holt and Gorton governments that had been left in the office by former press secretary Tony Eggleton. MacDonald subsequently delivered some of these papers to the Liberal Party secretariat, retained others for further sorting and consigned the remainder to the then Commonwealth Archives. MacDonald was aware that in doing so he had disobeyed McMahon's instructions. According to a record of a subsequent phone call, MacDonald had 'taken the view that, because of the nature of the papers [he had taken home for sorting], they should be boxed separately according to the prime ministership and sealed and delivered to the custody of the Archives'. When contacted by the National Library about these papers, he was told that he had been wrong to send them to the archives. McMahon's contact at the 
library, a Dr Fenning, had 'disagreed with him [MacDonald] that [the] Archives was the appropriate place for the papers and had said it was only appropriate for official papers, not personal papers, to go to archives'. ${ }^{4}$

The division made here, between official and private papers, was to become a faultline in the handling of McMahon's papers, and the basis for McMahon's control of them. For, in April 1973, having been contacted by the National Library, having heard of MacDonald's actions, and now receiving word of plans by PM\&C to check for any 'official material' among the papers now held by the archives, McMahon reacted quickly. He telephoned Sir John Bunting, secretary of PM\&C, and told him that 'he would regard the papers from the Eggleston/MacDonald office as being papers from the private office and therefore of the Min[ister]s.' personally'. In a subsequent call to a deputy secretary, Geoffrey Yeend, McMahon ordered the department to desist from any checking of the material. 'This was none of our business,' recorded Yeend, of this conversation. 'He would make any separation into official or private.' In the meantime, all of the papers concerned were to be delivered to the National Library. MacDonald, McMahon said, had been presumptive and had defied instructions. ${ }^{6}$

McMahon was adamant that all of the papers from his office were his. His transfer of the papers to the library came with condition that this was acknowledged: 'I have confirmed with Mrs Fanning that the documents will be retained in your custody,' he wrote to the library, in April 1973, 'until I have occasion to request them and that ownership and control will, of course, remain with me whilst they are in your custody. ${ }^{7} \mathrm{He}$ was willing to fight to force both the archives and PM\&C to accept that. He contacted former prime ministers Menzies and Gorton, and Dame Zara Bate (widow of Harold Holt), to obtain agreement where the papers relating to their prime ministerships that had been recovered from the press office should go. He claimed ownership of files that were 'of a continuing nature' in the prime ministerships of Menzies, Holt, Gorton and himself. ${ }^{8}$ In June 1973, he telephoned another deputy secretary of PM\&C, Peter Lawler, to insist that all of the papers were 'his personal papers', that 'there were no provisions in Australia to deny this', and that if the matter were not resolved in his favour then he would 'either approach the prime minister or go to his solicitors'.?

Advice tendered to Bunting, Lawler and Yeend by their department provided little clarity on what should be done. The advice noted that 'there is no satisfactory definition of the distinction between private and official papers', and that individual

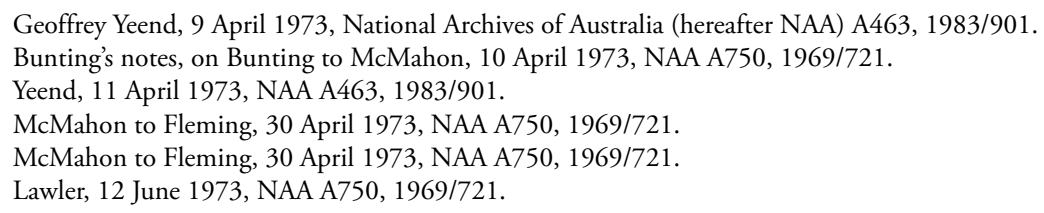


documents could very easily fall into one category or the other-or both. Yet it also advised that the National Library was an inappropriate custodian for papers that were official and/or classified, such as cabinet documents, as the library did not apply 'government access policy to official material in its custody'. The best outcome, the advice went, would be for the whole of the McMahon papers to be deposited in the archives. The related issue, of ownership, remained vexed. The legal position was far from clear; there would doubtless be political pressure over the matter; and any interim or premature surrender of the papers would make getting them back far more difficult than maintaining them. ${ }^{10}$

Lawler believed that the problem of the McMahon papers needed to be resolved quickly. He wanted nothing to upset the lately announced Whitlam Government intentions to reform the national archives system. In conversations with colleagues in September 1973, Lawler said that he would 'prefer at this stage to "lose a battle but win the war", and did not want to 'fight in the ditch' over the matter. ${ }^{11}$ Thus the decision to give in. Lawler agreed to transfer all of the McMahon papers from the archives to the library on the understanding that papers in the collection deemed to be 'other than private papers' would be held under the same custody and access provisions as at the archives.

The library, meanwhile, was grateful but also wary. In January 1973, having received four filing cabinets 'full to bursting with folders' of material relating to McMahon's period as Treasurer, library officials had been alarmed to discover that half of the papers were classified up to secret and top secret level, with a large component also of original Treasury minutes and cabinet documents. They had reached out to the Department of Foreign Affairs for advice on sensitive departmental cables, which in turn contacted PM\&C, which quickly took custody of the material and placed it with the archives-and thus prompted McMahon's calls shortly thereafter. ${ }^{12}$ The bulk of that material, sans at least some of that classified material, was subsequently returned to the library in December $1973 .{ }^{13}$

The flurry of correspondence and calls in 1973 left McMahon disdainful of the archives and unwilling to countenance their involvement in the handling of papers that he claimed as his own. It also served to leave archive officials wary of McMahon and concerned about the papers held by the library. Recapitulating the aforementioned events a decade later, archivist David Easter concluded: 'Mr. McMahon made it obvious during this course of events that he did not want any of his material to be in the custody of Archives. ... An approach should definitely not be made to McMahon or to his staff offering our personal archives services. ${ }^{.14}$

10 Hurley, 21 June 1973, NAA A750, 1969/721.

11 Scott, 28 September 1973, NAA A750, 1969/721.

12 Walker, 17 January 1973, NAA A750, 1969/721.

13 Powell to Dunner, 4 December 1973, NAA A750, $1969 / 721$.

14 Easter to the Archives NSW Regional Office, 30 July 1982, NAA A463, 1983/901. 
McMahon's aim in entrusting custody of the papers to the library over the archives was threefold: first, he wanted to resolve in his favour the question of ownership of the papers. Second, he wanted to retain control of access to the papers. Third, he wanted to ensure that the papers would be at his disposal when the time came. ${ }^{15}$ He would be successful on the second and third aims, but the first would continue to be the object of contest.

When he retired in 1982, and announced he would commence work on his autobiography, McMahon requested the papers be sent to the office he had set up in Westfield Towers, Sydney. The library sent the whole of the McMahon papers-now filling 22 filing cabinets-to McMahon in May the following year and expressed a wish that he return them once he had finished his autobiography. ${ }^{16}$ McMahon gave this short shrift. 'May I put, only for accuracy purposes,' he wrote, 'that the words "on loan" do not accurately reflect the ownership of the papers. In the original letter written I said that the property would remain with me; you agreed to this. ${ }^{17}$ The library quickly conceded the point: 'We have noted that the papers remain your property and are glad to consider it highly probable that they will be returned to the National Library on completion of your book or books. ${ }^{18}$

McMahon's sense of proprietorship was hardly unique. Malcolm Fraser, who lost office to Bob Hawke at around the same time as the papers were returned to McMahon, was affronted by the way in which functionaries from the archives swept his office clear of documents and subsequently mixed official papers with what he believed were personal papers. As Gideon Haigh reported of Fraser's subsequent efforts to unscramble this omelette:

Many files had become commingled, and the NAA [National Archives of Australia] at first insisted on the broadest possible definition of what was theirs: any folder, no matter how much personal correspondence it contained, in which reposed a Commonwealth document, no matter how minor ... At one stage, a University of Melbourne reference archivist, Katie Wood, spent seven weeks in Canberra evaluating key documents; at great expense, Stephen Charles, QC was jointly retained to provide clarifying definitions. ${ }^{19}$

But there would be no such moment of settlement for the papers that McMahon claimed. For while he now had custody of the papers and, in his view, settled the question of their ownership, officials within the public service continued to nurse doubts and concerns. When Brian Toohey reported in May 1983 that McMahon's home had been bugged by ASIO (Australian Security Intelligence Organisation)

15 W. D. Richardson, acting National Librarian, quoted McMahon to this effect: see Richardson to Lawler, 15 October 1973, NAA A750, 1969/721.

16 Helson to McMahon, 9 May 1983, NAA A463, 1983/901.

17 McMahon to Santamaria, 2 May 1983.

18 Santamaria to McMahon, 5 May 1983.

19 Gideon Haigh, 2013, 'The Rise and Rise of the Prime Minister', Meanjin 72, no. 1 (Autumn 2013): 40-61. 
agents in the 1960s, McMahon wrote to ASIO to request a physical security assessment of his office. ${ }^{20}$ Notice of the subsequent inspection prompted PM\&C officials to recall that they had little idea of what papers McMahon had retained after leaving the prime ministership. They were aghast when they received a copy of the report, which noted that the inspecting ASIO officer was 'amazed' at the papers McMahon held. It was the nature of those papers that spurred the report's recommendations that an alarm system, false ceiling, approved shredder, and lockable power supply switch for the photocopier be installed in McMahon's office, and that the office's file storeroom be equipped with a mortise lock, microswitch and infrared intrusion detection system. ${ }^{21}$ PM\&C officials were averse to the quoted $\$ 22,000$ cost of these measures but alarmed by McMahon's continued custody of the papers: 'The issue that does concern this Department is that of retention by a former prime minister of highly classified official documents. ${ }^{22}$

Nothing, however, had been done about the matter by 1985. "We have reached the position where we are aware that Sir William McMahon is in "unauthorised" possession of a substantial number of Cabinet documents', ran a January 1985 note for file. It appears that what caused officials to hold back was repeated advice that McMahon was in the late stages of writing his autobiography and that the papers would be returned soon: 'Sir William has now finished his book and only some finishing touches are needed. In such an eventuality Sir William may well not need to retain many of the documents he presently holds. ${ }^{23}$ Another factor in the decision to hold back was McMahon's continued hostility to the archives and to separation of the papers. He would have 'no truck' with the archives and their processes; they would have no involvement with him. This left the problem with PM\&C alone. 'He has official documents, particularly cabinet papers, in his possession; he should be asked to return them,' officials insisted, privately. And yet, as they knew, McMahon would never agree to a divide of the papers along official and private lines: 'He does not appear to accept the distinction. ${ }^{24}$

Thus the department sought other ways to resolve the issue. As a note of a meeting with Geoffrey Yeend, now secretary of PM\&C, in September 1985 put it, the department would leave McMahon 'content alone' and, in the meantime, improve its relationships with the library and archives to ensure that official papers from then on were held by the archives only. ${ }^{25}$ And, while not willing to provide the money to

20 Brian Toohey, 'The Austeo Papers', National Times, 6 May 1983, 3-7.

21 ASIO director-general (security) to Yeend, 7 June 1983; Gallery to Lance, 30 June 1983; and Bell to Rosalky, 5 August 1983; all in NAA A463, 1983/901. What is also notable is that it appears little had been done to sort the papers. McMahon staffer Robert Ashley recalled that upon moving into Westfield Towers the boardroom was 'wall-towall paper'. 'When I arrived,' he said later, 'there were papers everywhere': personal interview, 28 November 2017.

22 Rosalky to Bell, 12 August 1983, NAA A463, 1983/901.

23 Steins, 22 January 1985.

24 Doepel to Selth and Jackson, 30 July 1985.

25 'Mr Selth: after discussion with Secretary', 2 September 1985. 
implement the ASIO-recommended measures in McMahon's office, the department agreed to install an approved safe to contain the sensitive material. In October 1985, PM\&C officials contacted McMahon's office to say that they would provide a B-class container, at a cost of $\$ 1,600$, for the storage of sensitive papers. But McMahon's staff were confused by the offer. The office had already 'three Chubb combination safes' in which to store sensitive material, they pointed out. That said, they added, there were still a considerable number of files around the office-files that might better be kept in a safe. ${ }^{26}$

\section{'My autobiography will be published'}

McMahon's claims about finishing his autobiography were repeated throughout the six years between his retirement and death. Before his retirement from parliament, one staffer recalled, the former prime minister was determined to write the bookeven anxious to do so. ${ }^{27}$ At a farewell press conference in 1982, he promised that the public would soon read the book and be amazed at its revelations. 'What we achieved in those twenty months [I was prime minister] was unbelievable,' he said at one point. ${ }^{28}$ 'When I tell of the things I had to put up with,' he said at another, 'none of you will believe it. ${ }^{29}$ In conversations in public and in private thereafter, McMahon spoke repeatedly of writing an autobiography that would also be a grand, historical chronicle, that would bridge the gap between participant and historian. ${ }^{30}$ Eschewing the anecdotage and partial stories that characterised the autobiographies of non-Labor politicians such as George Reid, Billy Hughes and Robert Menzies, McMahon's intentions appear to have been to mimic Churchill's efforts and style, drawing on records not yet public in order to write a work that was definitive. ${ }^{31}$

Given the enormous volume of papers that McMahon had assembled and maintained control of, he was well placed to write that work. The return of those papers was invaluable, as was the aid of staff members he retained under his entitlements as a former prime minister. So too, in spite of his reputation, was the status and prestige he possessed as a former prime minister.

In 1983, he attracted a literary agent after informing him that a manuscript was almost complete. That agent, Michael Morton-Evans, introduced McMahon to the Sydney-based publisher Thomas Nelson. But the publisher lost interest soon

\footnotetext{
26 Doeel to Selth and Jackson, 1 August 1985, and Templeton, 4 October 1985.

27 Robert Ashley, personal interview, 28 November 2017.

28 Hugh Crawford, 'My One Regret', Herald (Melbourne), 5 January 1982, 4.

29 Peter Rees, 'McMahon Quits in Protest', Sun (Sydney), 5 January 1982, 2.

30 Mark Hayne, 'The Autobiography That Never Was', Sydney Morning Herald, 11 April 1988, 15.

31 Reid explicitly called his 'reminiscences' only; Hughes wrote of 'stories' that remained reticent; and Menzies called his a 'patch-work quilt'. See W.M. Hughes, Crusts and Crusades (Sydney: Angus \& Robertson, 1947), v; Robert Menzies, Afternoon Light (Melbourne: Cassell, 1967), 2; George Reid, My Reminiscences (London: Cassell, 1917).
} 
after seeing the manuscript. According to Morton-Evans, they were aghast at its size, which was allegedly so voluminous that it would have run to four volumes. Morton-Evans's suggestion that McMahon make revisions to address this concern was brushed aside: 'The concept of someone fiddling with his words was anathema to him. ${ }^{32}$ Morton-Evans ceased to be his agent shortly afterward.

Towards the end of the year, however, this resistance had been eroded: McMahon was open to the idea of hiring an editor to work on the manuscript. The publisher at Williams Collins Ltd, Richard Smart, met with and impressed on McMahon the need for an editor while making clear that McMahon would not necessarily need to accede to wholesale revisions. ${ }^{33}$ Accepting this, McMahon began to cast around for help. He approached former public servants, academics and other authors, including Sir Halford Cook, Sir Henry Bland, Cameron Hazlehurst, Mark Hayne and Ian Wilson. In January 1984, on a recommendation from the chief of staff at the Sydney Morning Herald, McMahon approached David Bowman, a South Australian journalist and former editor of the Canberra Times and Herald who had left Fairfax in 1980 and since worked as a media critic. ${ }^{34}$ Bowman agreed to a sixmonth contract during which he would edit McMahon's manuscript to publishable length and quality.

Bowman's experiences provide a crucial window into McMahon's continuing efforts to control his story. Bowman's reaction to the voluminous manuscript written by McMahon and rejected by Thomas Nelson was unfavourable. He believed it poorly structured, full of irrelevant detail and overly fixated on the actions of others. A considerable amount of the material was already on the public record, and what was not was variously 'dull', 'hollow' and 'incomprehensible'. The material that officials in the public service were so concerned by does not appear to have been included in the manuscript; if it did, it did not much excite Bowman. Overall, he was blunt: 'It is very badly done. ${ }^{35} \mathrm{He}$ found, moreover, that the vast manuscript of which McMahon had begun to boast was nowhere near the oft-stated 400,000 words. Bowman's reading revealed duplication and extraneous material such as letters and unabridged speeches. 'By the time it's cut into shape,' Bowman wrote in his notes, 'we shall probably have no more than 50,000-60,000 words.' And yet, as he saw it, the problems were such that a mere edit would be insufficient to make the manuscript publishable. It needed to be almost entirely rewritten. ${ }^{36}$

32 Michael Morton-Evans, personal communication, 27 September 2016.

33 Richard Smart, personal communication, 24 August 2016.

34 See, for example, his later effort: David Bowman, The Captive Press (Ringwood, Vic.: Penguin, 1988).

35 Notes made by David Bowman, January 1984, in the author's possession.

36 David Bowman diary, 18 January 1984, in the author's possession. 
Bowman knew that this might be dangerous to suggest. When he first told McMahon that there were problems in the manuscript, he observed that McMahon's eyes narrowed to 'small blue spots'. ${ }^{37}$ Taking advice from McMahon's staff about how to handle this drastic recommendation, Bowman put his argument carefully, and was attentive to McMahon's pride. He undertook to ghost-write the revised manuscript, and argued in flattering terms that it was necessary that McMahon be the central figure of the autobiography: 'Only rarely should he step aside for some other character to dominate the stage. ${ }^{38}$ McMahon initially seemed willing to countenance a large-scale revision, though he apprehended that the nature of Bowman's employment would have to change if a revised manuscript would be produced. But he repeatedly questioned and reconsidered the argument. In midFebruary 1984, Bowman presented McMahon with drafts of two new chapters of a kind that might be used in a revised manuscript. McMahon returned them with comments saying that friends had insisted that his early life be in the book. ${ }^{39}$ Then, he expressed second thoughts about abandoning the first manuscript, speaking favourably of its limited scope and fixation on the powerful people he had known. Bowman now wondered whether McMahon was reconsidering the nature of the work. He asked if McMahon wished to produce an autobiography—in which events and people were presented sequentially, comprehensively, with documentation, as he had always said—or a memoir. McMahon replied that he wished to produce the latter.

This new desire threw Bowman; but what came to trouble him even further, and slowed work on the manuscript, was what at times appeared to be McMahon's failing memory and at others his insistence on the integrity of that memory. Bowman had been warned of this. One of McMahon's fellow staffers passed him a slip of poetry:

Ah! What avails Sir William's sense,

And what the cultured word,

Against the undoctored incident

That actually occurred. ${ }^{40}$

Stories Bowman had been told by McMahon's staffers had alerted him to quirks of McMahon's behaviour; what he observed in a fortnight of work left him aware those stories were likely to be true. He saw repeated lapses of memory, from the trivial and transient to the significant and problematic. 'He confuses periods as well

37 Bowman diary, 16 January 1984.

38 Bowman to McMahon, 12 March 1984, copy in the author's possession. These points were initially made orally but were put into writing in March amid a dispute over the manuscript's direction and the nature of Bowman's work. 39 Bowman diary, 20 February 1984.

40 Bowman diary, 5 March 1984. 
as forgetting names and places,' Bowman wrote. Aware of the effect it could have on the book, he lamented that McMahon had left the job so late: 'He should have written the book ten years ago.' ${ }^{41}$

The problem had infected the manuscript that Bowman was now trying to wholly rewrite, leaving what in Bowman's eyes were incredible claims that needed to be supported by evidence. McMahon claimed, for example, that Menzies's antipathy towards him was the result of the influence of Dame Pattie Menzies, who was supposedly angered by McMahon's supposed refusal to accede to her supposed wish that he marry her daughter. ${ }^{42}$ McMahon recalled significant differences in the ministry about the government's handling of the Suez crisis that were not recorded elsewhere: 'Can these versions be reconciled?' Bowman asked..$^{43}$ Then he had claims about the governor-general and his relationship with Harold Holt in the days and weeks preceding Holt's disappearance and death in 1967 . These claims astonished Bowman: 'That would have been a giant upheaval. It is difficult to believe now that it was ever in the realm of practical politics.' Mindful that this material would need to be supported, Bowman added: 'I think the reader will need to be persuaded. ${ }^{34}$

But McMahon appeared to regard persuasion with contempt. Again and again, he insisted on his version of events, even in the face of clear contradictions found in credible evidence. For example, McMahon insisted that the Queen and Duke of Edinburgh had been present at an event of controversy during McMahon's period as minister for the navy and air. Bowman pointed out that the timing of the event and the Queen and Duke's visit were months apart. To this, McMahon 'kept on and eventually trailed off into incoherencies'. ${ }^{45}$ On another occasion, the refusal to face up to the contradiction was brazen. McMahon claimed to have visited troops in Korea in Christmas 1952, and wished to have this recorded in the manuscript. Bowman found that McMahon's passport was dated with a 14 December 1952 return to Australia. This did not convince McMahon that he was mistaken: 'He was certain. ${ }^{46}$ McMahon suggested Bowman call Sir Thomas Daly, an army general who had been serving in Korea during McMahon's visit. Daly backed Bowman. 'He says he has a distinct memory of that Christmas and you were not there,' Bowman wrote to McMahon. 'He recalls your carrying a message from the Army Minister, Jos Francis, for delivery to the troops. However, the men were widely scattered and only a few could be brought together. ${ }^{37}$ To this, McMahon denied carrying

41 Bowman diary, 2 February 1984.

42 Bowman would later use this information when he wrote Dame Pattie Menzies's obituary. See 'Dame Pattie Menzies', Daily Telegraph (London), 21 August 1995, 19. For that daughter's response, see Heather Henderson, A Smile for My Parents (Sydney: Allen \& Unwin, 2013), 213.

43 Bowman to McMahon, 22 May 1984, in possession of the author.

44 Bowman annotation, 'Death of Holt, sixth draft', manuscript, p. 35, in possession of author.

45 Bowman diary, 28 February 1984.

46 Bowman diary, 20 February 1984. Bowman's emphasis.

47 Bowman to McMahon, 21 February 1984, copy in the author's possession. 
a message from Francis and said he would call Daly himself. Then McMahon cited the Parliamentary Handbook, said he was in Japan and Korea from November to December, and 'that should be good enough' for the manuscript. Bowman threw McMahon's passport onto the desk: 'Then what do I do-burn this?' McMahon brandished the Parliamentary Handbook and asked the same question. Bowman tried to point out that the Handbook was correct, that McMahon had been in Japan and Korea in November and December-but that it did not mean he was there at Christmas. McMahon would not hear it. He left Bowman's office, arguing as he went, only to return a few minutes later and announce, 'I don't want to pursue it further'. ${ }^{48}$

At least some part of the problem appeared to arise from the reliability of McMahon's records. In the filing cabinets that cluttered the Westfield Towers office were copious aides-mémoire that purported to be records of conversations and moments of significance. Yet these were suspect. First, McMahon could hardly be relied upon to make accurate records. His staff noted that his records reflected how he wished the conversations and moments had gone rather than necessarily what had happened in them. His memory, as one staffer said, was 'always shaded to himself. Always. ${ }^{49}$ Second, these aides-mémoire were the subject of repeated revision at the time of their making. As that same staffer wrote, later: 'He would repeatedly hone whatever he was working on, sometimes making six or seven drafts. It used to drive his secretaries mad! ${ }^{50}$ Third, those aides-mémoire continued to be subject to repeated revision for years afterward. McMahon would write additional notes on them, thereby corrupting the integrity of the original document by adding new material or reframing the record in light of subsequent events. Thus a lengthy aide-mèmoire about McMahon's relationship with John McEwen, originally drafted in 1967, in the wake of Harold Holt's death, continued to be revised and redrafted even after 15 years time. ${ }^{51}$

All of this caused Bowman's difficulties with McMahon to mount. By May 1984 McMahon was dissatisfied with progress, disliked the drafts Bowman was producing, and would not accept that rewriting the manuscript, as he had agreed, should actually involve rewriting. He wanted the book merely to be edited. He emphasised that editing was what the book's publisher, Richard Smart, had said. McMahon wanted the book published quickly: he claimed that if it did not come out by the end of 1984 then he would be forgotten. McMahon's attempts to have Smart act as an umpire between he and Bowman went nowhere, as did Bowman's repeated statements to McMahon that everything he produced was a draft, open

48 Bowman diary, 21 February 1984.

49 Peter Kelly, personal communication, 1 October 2016.

50 Peter Kelly, 'Politics the Day Holt Died', Australian, 13-14 December 1986, 2.

51 An unamended copy, 'Short history of difficulties with Mr. McEwen', may be accessed at NAA M3787, 32.

A copy bearing McMahon's handwritten, undated annotations and revisions is in the author's possession. 
to revision if he did not like it. Meetings to resolve the problems repeatedly trailed into irrelevancies and questions about obscure details and sources. In one especially digressive meeting, McMahon insisted that all that was necessary was to make the manuscript a bit more readable. The book had to be in his style, he told Bowman. ${ }^{52}$

Bowman, however, was by now so frustrated that he offered his resignation and left three weeks later, at the end of June 1984, noting as he did that McMahon was left with eight fully drafted and credible chapters. They could be redrafted and revised, of course, but otherwise were readable, coherent, shorn of repetition and adhered to accepted fact. Bowman did not think they would be used: 'None of this matters much, at this stage anyway,' he wrote, 'because Sir William has taken all the material referred to above, and rewritten it and restored earlier material. I have not seen the outcome.' 53

McMahon continued to work on the manuscript thereafter. In the wake of Bowman's departure he terminated his relationship with Richard Smart and Collins Ltd, and cycled through many of Australia's other publishers. A litany of ghostwriters, editors and aides also came and went. The most effective, it appears, was journalist Paul LePetit, who claimed to have brought the work to a near-publishable standard. McMahon continued to talk well of the book, proclaim that it would set everything straight, that it was all coming together. 'My autobiography will be published shortly and, I believe, it will be one of the most readable and interesting insights into Australian politics yet written ... I can assure everyone the book is well worth waiting for.' 54

But he would die, in March 1988, with the book unpublished. All work on it would cease. The papers that he had successfully kept in his control were packed into boxes for transfer to Canberra, to the National Library. Officials in PM\&C saw the opportunity to recover the papers they believed should never have been 'lent' to McMahon. Commenting on the letter sent to McMahon by the library in 1983, which conceded that the papers 'remain your property', officials were scathing. 'What do the Library think now-what steps are they taking to recover?'55

They contacted McMahon's staffers, hoping that they would help sort the papers and influence McMahon's widow, Lady Sonia McMahon, to agree to give back material that the officials believed were either on loan or Commonwealth property. Yet they were also wary about any suggestion that it was a matter for negotiation:

52 Bowman diary, 4 June 1984.

53 Bowman to George Campbell, 29 June 1984, copy in the author's possession.

54 William McMahon, 'A Good Read', Sydney Morning Herald, 10 July 1986, 14.

55 Post-it note annotation on Santamaria to McMahon, 5 May 1983, NAA A463, 1983/901. 
'With all due tact and sensitivity, we need to get the message across that decisions on Commonwealth records are not for the family to take,' wrote one official. ${ }^{56}$ Thus the letter to McMahon's secretarial staff on 5 May 1988:

We believe that Sir William may have had substantial numbers of Cabinet documents and other Commonwealth records including documents loaned to Sir William to aid him in the production of his autobiography. As a preliminary step it may be helpful for a member of my staff to visit you to undertake an initial survey of the extent of this holding and discuss with you the means by which these documents can be identified and our proposals on their future location. ${ }^{57}$

But Lady Sonia McMahon did not seem willing to revisit the point. Telling the public service to henceforth address this correspondence to her, she emphasised that the papers 'are the property of my husband'. ${ }^{58}$

It does not appear that the officials succeeded in going through those papers again. Files of the correspondence peter out in 1988. The McMahon papers were returned to the National Library, which holds them still, with access under the control of the McMahon family.

\section{'Perhaps this is the worst deceiver of all'}

Among my first acts when I began my biography of McMahon was to request access to his papers at the National Library and the cooperation of his family. Given the derision with which he had been treated, I prepared a proposal for the family that, I hoped, would show that I was committed to coming to a fair judgement of McMahon using sound historical practices. As I have documented elsewhere, in doing so I was attempting to address what I believed was the family's sensitivity towards writings about him. ${ }^{59}$ It was to no avail. My request for cooperation was refused and access to McMahon's papers was denied.

By the time of that decision I was well into the work and unwilling to cease. I had read many of the memoirs and autobiographies of McMahon's contemporaries, listened to oral history interviews, reached out to sources for interviews and begun to read material deposited in the National Archives of Australia. Not all that long after I received word of the family's decision, I accessed and read the files that documented McMahon's success at retaining control of official and private papers from his political career, and I spoke with David Bowman, who gave to

\footnotetext{
56 Annotation on Bonsay to Lucas, 26 April 1988.

57 Glanville to Woods, 5 May 1988.

58 Sonia McMahon to Glanville, 17 May 1988.

59 Patrick Mullins, 'Justifying the Profane: Ethics and Biography', in The Authorised Theft: Writing, Scholarship, Collaboration Papers - The Refereed Proceedings of the 21st Conference of the Australasian Association of Writing Programs, 28-30 November 2016, University of Canberra, Canberra.
} 
me a box disinterred from his basement containing papers gathered during his six months working for McMahon. Among the contents were typed extracts and drafts of McMahon's autobiography, letters, memos, notepads, payslips, Christmas cards, a plethora of aides-mémoire and-perhaps most illuminating-a loose-leaf diary that Bowman had maintained while working for McMahon. Vivid and detailed, bearing the newsman's instinct for what was important, the diary reiterated a point I was already coming to understand: that, having succeeded in keeping ownership and control of the archive of papers he had built up during the course of his career, McMahon remained determined, despite his failing health and memory, and despite the arguments of aides and editors, to similarly retain control of his life and story. McMahon's insistence on the autobiography being 'his style' was, in my view, not merely about grammar and syntax: it was about the substance and nature of the story told, the 'life myth' that he understood and wanted recorded for posterity. ${ }^{60}$

But the diary, the drafts and the extracts were also evidence of the failings and falsities of that life myth. Stories by their nature are selective, but those that McMahon told about himself and his life seemed especially so. ${ }^{61}$ In public comments and in drafts of the autobiography, McMahon portrayed himself as generally a wise, calm figure, always honourable, often vindicated by the turn of events, who was hardworking and energetic, who had risen to the top by dint of his efforts alone-and who had been wronged by jealous and malevolent colleagues, who had been hampered by the failings of less able peers, and whose qualities had never been understood by the public-at-large thanks to a partisan press. It was not a convincing portrayal, in part because the man emerging from it was so unblemished. The cynic in me thought of Orwell's assessment of Salvador Dali's memoirs: 'Autobiography is only to be trusted when it reveals something disgraceful. A man who gives a good account of himself is probably lying, since any life when viewed from the inside is simply a series of defeats. ${ }^{62}$

How had McMahon become so set on this patently false life story? Writing on the nature of autobiography, the American psychologist Jerome Bruner argues that the stories we tell about ourselves are constructed artefacts. There is a basic similarity between those stories and the life from which they have been constructed, and that similarity is due to the imitation that a story must make of life in order to be credible. But the autobiographical story-whether written in old age or offered in the heat of the moment-demands a reflexivity that creates the self that is present

60 James Walter, 'The "Life Myth", "Short Lives", and Dealing with Live Subjects in Political Biography', in Australian Political Lives: Chronicling Political Careers and Administrative Histories, ed. Tracey Arklay, John Nethercote and John Wanna (Canberra: ANU E Press, 2006), 29, doi.org/10.22459/APL.10.2006.04.

61 This was not a point that had occurred to me alone. See Mark Hayne, 'The Autobiography That Never Was', Sydney Morning Herald, 11 April 1988, 15.

62 George Orwell, 'Benefit of Clergy: Some Notes on Salvador Dali', in The Collected Essays, Journalism, and Letters of George Orwell, vol. 3: As I Please, 1943-1945, ed. Sonia Orwell and Ian Angus (London: Secker \& Warburg, 1968), 185. 
in that story; that is, the autobiographical narrative becomes self-fulfilling. 'In the end,' Bruner declares, 'we become the autobiographical narratives by which we "tell about" our lives. ${ }^{{ }^{63}}$ In this telling, it became clear that McMahon's story about his life, and his determination to see that story told in his autobiography, was the result of the imperative to explain who he was in 1982-88, when, in retirement, he was trying to redeem his ignominious reputation.

But why the abundance of contradictions between McMahon's story and those of his colleagues and those evidenced in records? Because, as Bruner also explains, the selectivity required of storytelling involves a fundamental distortion of the events they repute to relate. As the story is told and retold, the facts that might run counter to the story are slowly shorn off, worn away — and, in the end, forgotten by the teller. In Bruner's theory, McMahon's insistence on the correctness of his autobiography stemmed from an acute psychological need to be the subject of the story he told about himself. That story, like stones in a fast-moving river, had become worn and smooth in its constant retelling, to the point that McMahon believed it to be the truth and nothing else. He lived as its subject: as a man who had been wronged, whose reputation was in need of redemption via an autobiography, and who thus had to have reasons for that redemption. ${ }^{64}$

But this narrative had to be viable in the cross-streams of other stories. Bruner points out, citing Sartre, that life stories have to mesh with a whole community of other life stories. This occurs at both a structural level, in which stories may be shaped as (for example) tragedies or comedies, as well as a truthful, verifiable level, where readers would accept the claims contained therein. To surmise from his diary, Bowman accepted this. But McMahon could not. He could not accept a story that had to be supported so, nor accept a story that, in meshing with others, diverted so far from his. Hence his vehement reactions to Bowman's questions and his critical fact-checking. McMahon could not comprehend or fathom how they might be necessary. To answer and consider them might be to suggest that his story was wrong. But that could not be. His story was the real story. His story was the right one.

'Perhaps this is the worst deceiver of all,' wrote Doris Lessing, 'we make up our pasts. ${ }^{65}$ It seemed that McMahon, in acceding to that deep need to tell his story as he saw it and refusing to see that there could be other ways of seeing his story, had fallen victim to that deceit: he had ensured that his story would never be accepted,

63 Jerome Bruner, 'Life as Narrative', Social Research 71, no. 3 (Fall 2004): 691-710.

64 Mark Hayne would write later that McMahon seemed to have 'built up a protective barrier which screened out criticism of himself and which reinforced his perception of his importance in the eyes of history and the public': see 'The Autobiography that Never Was', 15.

65 Doris Lessing, Under My Skin: Volume One of My Autobiography (London: Harper Perennial, 1995), 13. 
let alone see the light of day. Hence the repeated failure, between 1982 and 1988, to produce a manuscript acceptable both to him and to the seven publishers to whom he submitted drafts before his death. ${ }^{66}$

\section{'A new and entirely different order of reality'}

In the absence of a published manuscript, it was almost inarguably the case that McMahon ceded control of the story of his life. Even before his death, his story was being told by others. When long-time colleague and intimate Peter Howson published a voluminous section of his diaries in June 1984, McMahon was outraged, claiming to have found errors and falsities in Howson's record: 'In each case Howson was a liar; emphatically a liar,' wrote Bowman. ${ }^{67}$ But the appearance of Howson's book and McMahon's adverse reaction were harbingers of the future. Amid a proliferation of published autobiographies and memoirs by non-Labor politicians in the 1980s, McMahon's reputation and story was taken from his hands and shaped by others. ${ }^{68}$ In the absence of his autobiography, the claims and views of colleagues and opponents went nearly unchallenged. ${ }^{69}$ Thus, in my view, the consensus about McMahon's life and his prime ministership had consolidated to the point where he was regarded as one of Australia's worst prime ministers.

I did not approach the task of McMahon's biography with any intent to rescue him from this ignominious plight. Nor did I approach McMahon with any intention of damning him further. I had neither hatchet nor halo in hand: I chose to write a biography about McMahon because, in the absence of both an existing biography and putative biographer, I could blaze a path across a field that was clear, hopefully meeting the methodological and ethical challenges presented by biography writing. This somewhat neutral regard for McMahon did not survive long. My reading about McMahon began to provoke what Richard Holmes calls 'the biographer's most valuable but perilous weapon': empathy. ${ }^{70}$ This arose, initially, from my curiosity about McMahon's autobiography and his failure to publish it. As I got further into my research, my interest and faith in the value of that interest unmistakeably-and uneasily_paralleled McMahon's. It was perhaps most acute when the journalist

\footnotetext{
66 'Works in Progress', Sydney Morning Herald, 19 February 1988, 26; Robin Hill, 'The Story Behind Sir Billy's Own Story', Sydney Morning Herald, 3 October 1987, 11.

67 Bowman diary, 4 June 1984.

68 Sean Scalmer has written persuasively on the proliferation of political memoirs and diaries in Australia: see Sean Scalmer, 'The Rise of the Insider: Memoirs and Diaries in Recent Australian Political History', Australian Journal of Politics and History 56, no. 1 (2010): 82-104.

69 Paul Hasluck's The Chance of Politics, ed. Nicholas Hasluck (Melbourne: Text, 1997), is perhaps the most famous and enduring.

70 Richard Holmes, 'A Quest for the Real Coleridge', New York Review of Books, 18 December 2014, accessed 29 November 2020, www.nybooks.com/articles/2014/12/18/quest-real-coleridge/.
} 
Alan Ramsey asked, in a tone of beggared disgust, why on earth I was doing the project. I had to catch myself from bleating, per McMahon, that I thought it would be interesting and worthwhile.

Then there was the empathy that was provoked by Bowman's diary. The dilemmas that he had faced paralleled my own. Already, each and every day, in what I was doing and what Bowman had attempted to do, I saw an abyss: between what the manifold documents could and could not establish; what the individuals I was listening to in person or on CDs at the National Library could recall, forget and believe; between different ways of reading and understanding the past; between reality and perception; between truth and falsity. Bowman had repeatedly asked himself the same question that I was asking: What actually happened? In no small way, thanks to McMahon, Bowman had been unable to answer that question. I was determined to find answers, but I could not help but feel that a string of failures undermined the ontological certainty of my biography of McMahon even as I was writing it.

This was particularly acute when I probed claims whose basis could not be tested or known. Bowman had noted a conversation with McMahon about the origins of the Aged Persons Homes Act. Passed by the Menzies Government in 1955, it had allowed the federal government to match, on a pound for pound basis, private donations to the construction and maintenance of nursing homes. The Bill had provided a model for subsequent schemes to build women's refuges, and housing for the young and Indigenous. Reputed to have been the idea of Dame Pattie Menzies, McMahonaccording to Bowman's notes-claimed differently. I was ready to discount the claim when I turned the page to read about a phone call Bowman had subsequently made to McMahon's parliamentary colleague Billy Wentworth. Bowman had raised the claim and Wentworth had confirmed its veracity. There was no further mention of it in the notes and papers. ${ }^{71}$ What to make of it? There might well have been material on the point among McMahon's papers in the National Library-but how to be sure? How to know?

It was a similar case when I studied John Gorton's fall from office. It is widely believed that McMahon — barring his backgrounding against Gorton—had no hand in the matter. But Malcolm Fraser, whose resignation from the defence ministry had sparked Gorton's fall, was suspicious that McMahon had been involved, principally by leaking word that the Joint Intelligence Organisation was compiling reports on the Army's efforts at 'Vietnamisation' in Vietnam. This information, spun as suggestion that there were problems between Fraser and the Army, was central to the conflict that gave Fraser impetus to resign. ${ }^{72}$ Was McMahon involved?

71 Bowman diary, 5 April 1984.

72 Malcolm Fraser interviewed by Clyde Cameron, February and April 1987, National Library of Australia Oral History, TRC 2162, 350. 
This kind of unanswerable question added to the challenge I was already grappling with, as articulated by James Olney:

If bios is 'the course of a life, a lifetime', and if it is already spent and past, then how is it going to be made present again, how is it ever going to be recaptured, how is that which is no longer living going to be restored to life? When 'is' has been transformed into 'was', when the unique moment of the present slips into the huge abyss of the past, if it remains in any sense real at all, then it must be within a new and entirely different order of reality from that informing the present. ${ }^{73}$

In the description of the challenge, however, lay the solution. Olney's passage offered permission and opportunity to eschew the kind of dutiful 'claim, counter-claim, evaluation' that would otherwise have clogged the pages of my biography. The 'new and entirely different order of reality' suggested a way to acknowledge the inability to resolve claims like the above and reflect on the meaning and ramifications of that inability. Perhaps even more notably, it also became a way to portray and understand the story that McMahon told about himself - the life myth that he persisted so earnestly and doggedly to try to put forward in his autobiography.

Using the documents and material that Bowman had given me, I could recreate the years where McMahon and his ghost-writers had tried to present this story, paralleling their efforts: just as I was trying to ascertain the facts, so too had Bowman and the scores of other ghost-writers that McMahon had employed. I could portray, discuss and contextualise their efforts, implicitly drawing attention to my own, and describe how and why those gaps had opened up. I could show how McMahon had come to see himself-and why his views diverged so far from his colleagues and peers. I could also show how and why McMahon's reputation had been formed, and how and why he had failed, ultimately, to write the autobiography that he had promised. Moreover, rather than banish this material to a concluding chapter at the end of the book—as a strict chronological approach would have had it-I could make it the central thread of the biography. Intertwining an orthodox biographical narrative that was, as much as possible, fact-based with an account of McMahon's attempts to write the story that he believed in, I could draw the reader's attention to the problems and limits of recreating the past, of understanding a life, of writing a type of 'history'. In sum, that 'new and entirely different order of reality' thus took on a rather literal meaning: a biography that reckoned with the 'life' and the 'stories' of William McMahon.

73 James Olney, 'Some Versions of Memory/Some Versions of Bios: The Ontology of Autobiography', in Autobiography: Essays Theoretical and Critical, ed. James Olney (Princeton, NJ: Princeton University Press, 1980), 237. 


\section{Who owns the life?}

Ownership remains a vexed question in biography. As James Walter points out, there are many stakeholders in a biography-from the subject to their family and friends, to their colleagues and peers, to the wider public that may never interact with a subject but live nonetheless in a country affected by them. McMahon's children, who now perhaps have greatest claim to an ownership, never commented on my book, though one of McMahon's nephews wrote to insist, notwithstanding that he had not read the book, that I had certainly got his uncle wrong. He might well be right. The McMahon family's refusal to cooperate with me means that there are facets of his character that I was not able to capture; their refusal to allow access to McMahon's papers, at the National Library of Australia, means that I was unable to take into account information that might well be contained there. It may well be that another biographer, who wins access and cooperation, comes to a very different view of McMahon than that portrayed in my book. Until this time, however, the silence of the family and the restrictions on his papers reiterates the truth of McMahon's declaration in 1973: 'Ownership and control will, of course, remain with me. ${ }^{74}$ 
This text is taken from Australian Journal of Biography and History: No. 5, 2021, published 2021 by ANU Press, The Australian National University, Canberra, Australia.

doi.org/10.22459/AJBH.05.2021.07 